\title{
In-vitro model systems to study Hepatitis C Virus
}

\author{
Usman Ali Ashfaq ${ }^{1 *}$, Shaheen N Khan', Zafar Nawaz ${ }^{2}$ and Sheikh Riazuddin ${ }^{3}$
}

\begin{abstract}
Hepatitis C virus (HCV) is a major cause of chronic liver diseases including steatosis, cirrhosis and hepatocellular carcinoma. Currently, there is no vaccine available for prevention of HCV infection due to high degree of strain variation. The current treatment of care, Pegylated interferon $\alpha$ in combination with ribavirin is costly, has significant side effects and fails to cure about half of all infections. The development of in-vitro models such as HCV infection system, HCV sub-genomic replicon, HCV producing pseudoparticles (HCVpp) and infectious HCV virion provide an important tool to develop new antiviral drugs of different targets against HCV. These models also play an important role to study virus lifecycle such as virus entry, endocytosis, replication, release and HCV induced pathogenesis. This review summarizes the most important in-vitro models currently used to study future HCV research as well as drug design.
\end{abstract}

\section{Introduction}

$\mathrm{HCV}$ infection is a serious global health problem that affects 180 million people worldwide and 10 million people in Pakistan [1]. It is estimated that three to four million people are infected with HCV every year. HCV causes acute and chronic hepatitis which can eventually lead to permanent liver damage and hepatocellular carcinoma [2]. Of those acutely infected with $\mathrm{HCV}$, around $85 \%$ develop chronic infection. Approximately $70 \%$ of patients with chronic viremia develop chronic liver disease, $10-20 \%$ of which develop liver cirrhosis. Hundreds of thousands of people die each year from liver failure and liver cancer caused by this disease.

$\mathrm{HCV}$ is a small enveloped virus with a positive sense, single-stranded RNA genome that encodes a large polyprotein of 3010 amino acids. The polyprotein is co- and posttranslationally processed by cellular and virally encoded proteases to produce four structural (Core, E1, E2 and P7) and six non-structural (NS2, NS3, NS4A, NS4B, NS5A, NS5B) proteins [3,4]. Among the structural protein, $\mathrm{HCV}$ envelop protein E1 and E2 are highly glycosylated and play an important part in cell entry. HCV NS3 serine protease and NS5b play an important role in replication. HCV NS3 serine protease, NS5B RNA-dependent RNA polymerase and HCV structural proteins are important targets for antiviral drug development (Figure 1).

\footnotetext{
* Correspondence: usmancemb@gmail.com

${ }^{1}$ Division of Molecular Medicine, National Centre of Excellence in Molecular Biology, University of the Punjab, Lahore, Pakistan

Full list of author information is available at the end of the article
}

On the basis of nucleotide variation $\mathrm{HCV}$ is divided into six major genotypes and more than 80 subtypes. There is $30-50 \%$ variation among viral genotypes and $15-30 \%$ among different subtypes while there is $1-5 \%$ variation in nucleotide sequence from a single $\mathrm{HCV}$ infected patient $[5,6]$. They occur in different proportion in different parts of the world. Genotype 1a and $1 \mathrm{~b}$ are the most common genotypes in the United States and Europe $[7,8]$. The most prevalent HCV genotype in Pakistan is 3a followed by $3 \mathrm{~b}$ and 1a [9].

Presently, there is no vaccine available for prevention of $\mathrm{HCV}$ infection due to high degree of strain variation. Current therapeutic options for hepatitis $\mathrm{C}$ are limited, especially for genotype 1 . For genotypes 2 and 3 , pegylated interferon in combination with ribavirin, can lead to a sustained virological response in up to $80 \%$ of patients [10]. However, the therapy is expensive and often associated with side effects that may lead to discontinuation of therapy [11]. Hemolytic anemia, cough, shortness of breath \& treatogenicity are the most common adverse effect associated with ribavirin treatment, and muscle aches, fatigue \& neuropsychiatric adverse effects of IFN- $\alpha$ lead to premature cessation of therapy in 10 to $20 \%$ of patients $[12,13]$. Moreover, cost of interferon for 6 month treatment ranging from PKR 50,000 to 150,000 is beyond the financial range of most patients. Hence, there is need to develop anti HCV agents, both from herbal sources and synthetic chemistry which are less toxic, more efficacious and cost-effective. In this review, we summarizes the most important in-vitro
C Biomed Central

(c) 2011 Ashfaq et al; licensee BioMed Central Ltd. This is an Open Access article distributed under the terms of the Creative Commons Attribution License (http://creativecommons.org/licenses/by/2.0), which permits unrestricted use, distribution, and reproduction in any medium, provided the original work is properly cited. 


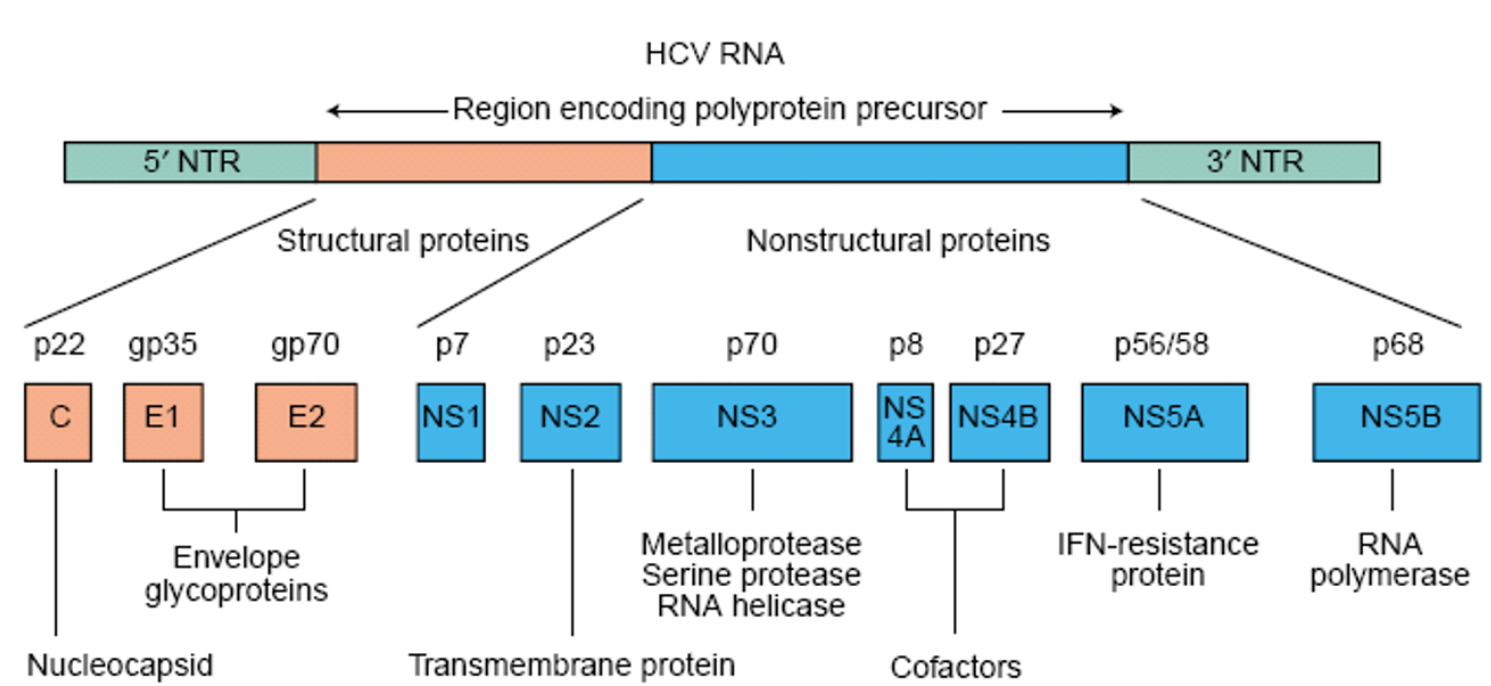

Figure 1 Proteins encoded by the HCV genome. HCV is formed by an enveloped particle harbouring a plus-strand RNA of 9.6 kb. The genome carries a long openreading frame (ORF) encoding a polyprotein precursor of 3010 amino acids. Translation of the HCV ORF is directed via a 340 nucleotide long 5' nontranslated region (NTR) functioning as an internal ribosome entry site; it permits the direct binding of ribosomes in close proximity to the start codon of the ORF. The HCV polyprotein is cleaved co- and post-translationally by cellular and viral proteases into ten different products, with the structural proteins (core (C), E1 and E2) located in the N-terminal third and the nonstructural (NS2-5) replicative proteins in the remainder. Putative functions of the cleavage products are shown [4].

models currently used to study future HCV research as well as drug design.

\section{HCV Infection System}

In the past, research into $\mathrm{HCV}$ has been hampered due to lack of a reliable cell culture system. Conventional virological methods failed to initiate productive $\mathrm{HCV}$ infection. With the passage of time, new molecular techniques made it possible to develop an efficient in-vitro culture system to facilitate the study of HCV. Initial attempts to established HCV infection used primary cells from humans and chimpanzees. Primary human foetal hepatocytes infected with $\mathrm{HCV}$-containing sera detected the positive strand of virus but the replication is low [14]. Human fetal hepatocytes supported HCV replication after infection with patient sera of $1 \mathrm{a}, 1 \mathrm{~b}, 2 \mathrm{a}, 2 \mathrm{~b}$, and $3 \mathrm{HCV}$ genotypes. HCV infected hepatocytes released $\mathrm{HCV}$ into medium for at least 2 month and $\mathrm{HCV}$ core protein and $\mathrm{HCV}$ negative-strand RNA also detected in infective cells. Viral replication had some cytotoxic effects on the cells due to production of interferon as a component of the antiviral response [15].

Due to short passage life and contamination problems in primary hepatocytes, scientists tried to develop immortalized human hepatoma cell lines. Many cell lines supported HCV infection and replication in-vitro such as Human T-lymphocyte cell lines, human fibroblast cells (VH3), peripheral blood mononuclear cells (PBMCs) and hepatocytes. But, hepatocytes are the target cells for HCV replication. Hepatoma cell line 7721 is susceptible to HCV by incubation of cells with HCV infected serum. HCV RNA is detected for at least three months following infection. This result also suggested that if the HCVinfected hepatoma cells were co culture with PBMCs, they were able to transfer the virus into PBMCs [16].

A human hepatocyte cell line, $\mathrm{PH} 5 \mathrm{CH}$, which is immortalised with simian virus 40 large antigen, was extensively studied. Although found to be more susceptible to $\mathrm{HCV}$ infection than others, the system was still inefficient [17]. Studies looking at hepatoma cell lines HepG2 and HuH-7 gave poor results even though conditions were changed extensively to try to optimise the approach $[18,19]$. Mizutani looked at infection of the human T-cell line, MT-2, which harbours human T-cell leukaemia virus-1 (HTLV-1). Although susceptible to HCV infection, it was not possible to produce long-term infection. Infection of Daudi cells, a B-lymphoplastoid cell line, managed to produce long-term infection for up to 1 year [20] but addition of the virus led to cellular cytopathic affects. It was possible to infect a chimpanzee with supernatant obtained after 58 days of culturing in Daudi cells, but infectivity was low. Other attempts were made to culture virus directly from cells of infected liver biopsies from persistently infected patients [21]. However, replication efficiency was low and reproducibility of the system was poor.

\section{HCV sub-genomic replicon}

The HCV replicon system replicates a modified HCV genome to high levels in human hepatoma (Huh-7) 
cells [22,23]. Replicons are either subgenomic (containing only the non-structural proteins for RNA replication) or genomic in length (contains the entire $\mathrm{HCV}$ genome). Both types of replicons contain the neomycin phosphotransferase gene for selection. A bi-cistronic replicon was created with the inclusion of an encephalomyocarditis virus (EMCV) IRES before the HCV nonstructural genes. All genes are driven by a T7 promoter. Following transcription with T7 RNA polymerase, replicon RNA is transfected into Huh-7 human hepatoma cells. RNA replication allows cells to grow and form colonies in the presence of the antibiotic G418 (Figure 2).

Some Replicons containing a luciferase gene to replace the neomycin phosphotransferase gene were used in transient assays to identify adaptive mutations. The replicon acquired adaptive mutations by unknown mechanism. Adaptive mutations are generally detected in NS3, NS5A and NS5B proteins [22,24]. Adaptive mutation in NS5A region causes interferon resistance. The highly adapted 5.1 replicon contained three adaptive mutations (two in NS3 and one in NS5A). These adaptive mutation strongly increase RNA replication [25].

A full-length clone bearing three adaptive mutations was not infectious to chimpanzees, while a clone bearing one adaptive mutation could infect and this mutation reverted back to wild-type [26]. Cellular factors were also important for replicon establishment in cell culture.
Replicons of passage number 128 replicated 100 -fold more efficiently than those in cells at passage number 15 [24]. Characterization of cells that harbored replicons showed that they were able to maintain autonomously replicating RNA for over one year. Furthermore, viral RNA was still detectable 10 months after removal of selection by neomycin. Replicon-bearing cells showed no obvious signs of cytopathogenicity. Viral proteins were localized to ER membranes and replication and expression were linked to the cell cycle [27]. Long term treatment of replicon-harboring cells with IFN- $\alpha$ effectively removed or "cured" cells of the replicon [28]. Subgenomic replicons, have been extremely useful for the screening of chemical libraries for novel molecules with antiviral actions against $\mathrm{HCV}$.

\section{Infectious HCV virion}

Recent studies have led to the development of infectious HCV culture systems. Wakita and his colleague developed genotype $2 \mathrm{a}$ full length replicon (JFH-1) which was isolated from a Japanese patient with fulminant hepatitis. This HCV full length genome replicates efficiently and produce virus particle (HCVcc) in Huh- 7 [29]. Chimaeric constructs of JFH-1 with the structural region of the J6 genotype 2a clone improved the infectivity [30].

Further refinements have led to the development of Huh7 derived cell lines (Huh7.5.1) which result in increase the viral titer $10^{4}-10^{5}$ infectious units per $\mathrm{ml}$ of culture supernatant and these cell lines are highly

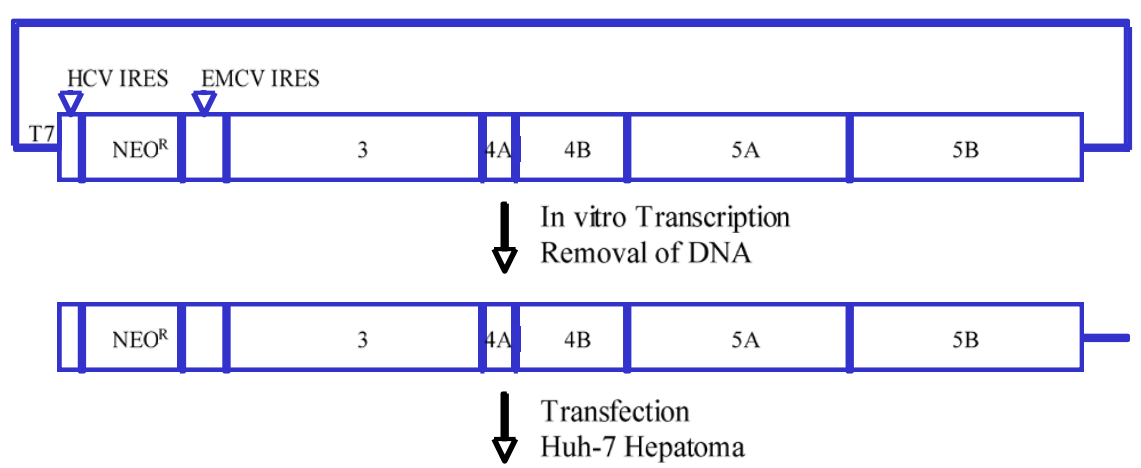

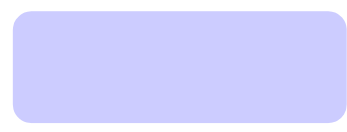

No RNA

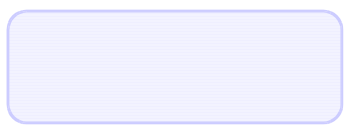

Cell Death

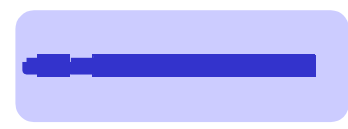

No Replication

G418 Selection

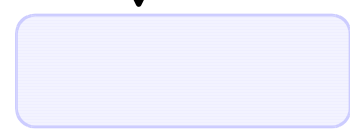

Cell Death

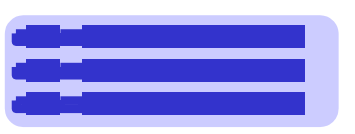

Replication

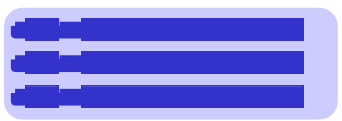

Colony

Figure 2 The HCV subgenomic replicon system 
permissive to JFH-1 virus infection [31]. JFH-1 infectious particle is an ideal tool to study all aspects of the $\mathrm{HCV}$ life cycle including viral attachment, entry, trafficking, replication. Virus particles can be neutralized with CD81 antibody and monoclonal antibody against the viral glycoprotein E1 and E2 [32]. HCVcc replication can also be inhibited by interferon-alpha and by several $\mathrm{HCV}$-specific antiviral compounds, suggesting JFH-1 infectious culture system, is a powerful tool to study antiviral drugs and vaccines. But, there are some limitation to use JFHI infectious particles such as these particles isolated from Fulminent Hepatitis which is rare event in hepatitis. Another important limitation that $\mathrm{HCV}$ particles is based on genotype 2 which is not dominant genotype in world and Pakistan.

\section{HCV producing Pseudo particle (HCVpp)}

HCV pseudotype particles were produced to study the early stages of viral life cycle. HCVpp were produced by transfecting the three vectors in Human embryo kidney cells (293T). The first vector encodes retroviral Gag and
Pol proteins which are responsible for particle budding at the plasma membrane and RNA encapsidation. The second vector encodes a reporter protein (Luciferase) or GFP. The third vector encodes HCV glycoproteins E1 and E2, which are necessary for viral tropism and fusion of HCV pseudo type particles with target cell membrane. 293T cells secreted virus pseudo particle an average $10^{5}$ particles $/ \mathrm{ml}$, which can be used to infect Huh 7 cells and infectivity is eveluated by quantification of amount of luciferase or GFP expressed in Huh-7 cells. These virus like particles can be neutralized with monoclonal antibody against the viral glycoprotein E1, E2 and sera of HCV infected patient $[32,33]$ and are a powerful tool to identify inhibitors which block HCV entry. HCVpp are also essential to find out fusion mechanism of virus (Figure 3).

\section{Conclusion}

$\mathrm{HCV}$ infection is a serious global health problem necessitating effective treatment. Currently, there is no vaccine available for prevention of $\mathrm{HCV}$ infection due to

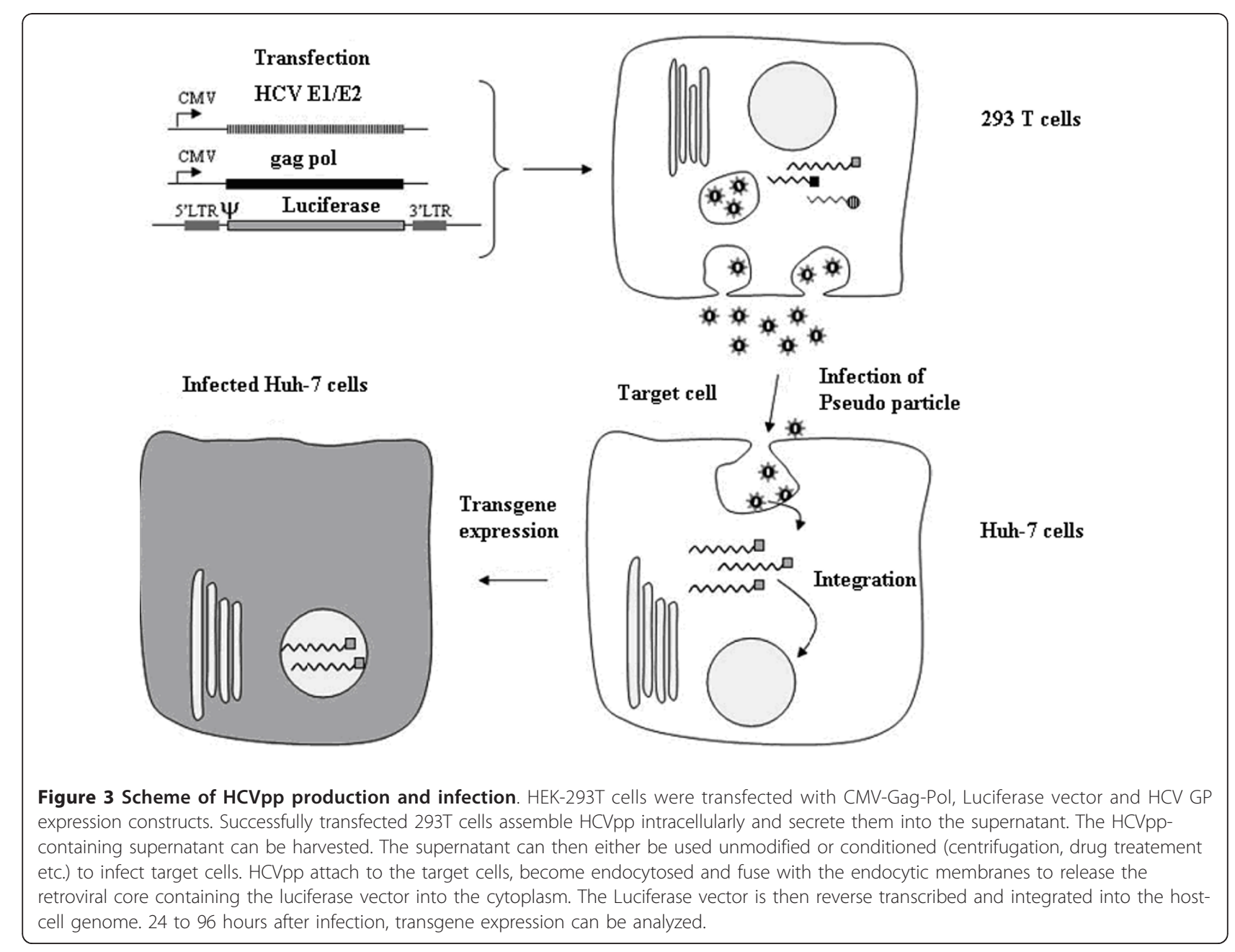


high degree of strain variation. The current treatment of standard, Pegylated interferon $\alpha$ in combination with ribavirin is costly, has significant side effects and fails to cure about half of all infections. The development of robust, cell-based replication and entry systems such as HCV sub genomic replicons, HCVpp and Cell culture producing virion will certainly accelerate the anti-HCV drug development process. With determination and innovation, we will undoubtedly meet the medical needs of those chronically infected with $\mathrm{HCV}$.

\section{Author details}

${ }^{1}$ Division of Molecular Medicine, National Centre of Excellence in Molecular Biology, University of the Punjab, Lahore, Pakistan. ${ }^{2}$ Braman Family Breast Cancer Institute, University of Miami, USA. ${ }^{3}$ Allama labal Medical College, University of Health sciences, Lahore, Pakistan.

\section{Authors' contributions}

UAA, SNK, ZN, SRD contributed equally in manuscript write up. All the authors read and approved the final manuscript.

\section{Competing interests}

The authors declare that they have no competing interests.

Received: 18 February 2011 Accepted: 6 April 2011

Published: 6 April 2011

\section{References}

1. Raja NSJK, Janjua KA: Epidemiology of hepatitis C virus infection in Pakistan. J Microbiol Immunol Infect. J Microbiol Immunol Infect 2008, 41:4-8.

2. Berenguer M, Lopez-Labrador FX, Wright TL: Hepatitis C and liver transplantation. J Hepatol 2001, 35:666-678.

3. Beaulieu PL, Tsantrizos YS: Inhibitors of the HCV NS5B polymerase: new hope for the treatment of hepatitis $\mathrm{C}$ infections. Curr Opin Investig Drugs 2004, 5:838-850.

4. De Francesco R, Tomei $L$, Altamura S, Summa V, Migliaccio G: Approaching a new era for hepatitis $C$ virus therapy: inhibitors of the NS3-4A serine protease and the NS5B RNA-dependent RNA polymerase. Antiviral Res 2003, 58:1-16.

5. Bukh J, Miller RH, Purcell RH: Genetic heterogeneity of hepatitis C virus: quasispecies and genotypes. Semin Liver Dis 1995, 15:41-63.

6. Simmonds P, Holmes EC, Cha TA, Chan SW, McOmish F, Irvine B, Beall E, Yap PL, Kolberg J, Urdea MS: Classification of hepatitis $C$ virus into six major genotypes and a series of subtypes by phylogenetic analysis of the NS-5 region. J Gen Virol 1993, 74(Pt 11):2391-2399.

7. McOmish F, Yap PL, Dow BC: Geographical distribution of hepatitis C virus genotypes in blood donors: an international collaborative survey. $J$ Clin Microbiol 1994, 32:884-892.

8. Nousbaum JB, Pol S, Nalpas B, Group atCS: Hepatitis C virus type 1b (II) infection in France and Italy. Ann Intern Med 1995, 122:161-168.

9. Idrees $M$, Riazuddin S: Frequency distribution of hepatitis $C$ virus genotypes in different geographical regions of Pakistan and their possible routes of transmission. BMC Infect Dis 2008, 8:69.

10. Flamm SL: Chronic hepatitis C virus infection. Jama 2003, 289:2413-2417.

11. Cornberg M, Wedemeyer H, Manns MP: Treatment of chronic hepatitis C with PEGylated interferon and ribavirin. Curr Gastroenterol Rep 2002, 4:23-30.

12. Khakoo S, Glue P, Grellier L, Wells B, Bell A, Dash C, Murray-Lyon I, Lypnyj D Flannery $B$, Walters $K$, Dusheiko GM: Ribavirin and interferon alfa-2b in chronic hepatitis $C$ : assessment of possible pharmacokinetic and pharmacodynamic interactions. Br J Clin Pharmacol 1998, 46:563-570.

13. Russo MW, Fried MW: Side effects of therapy for chronic hepatitis $C$. Gastroenterology 2003, 124:1711-1719.

14. lacovacci S, Manzin A, Barca S, Sargiacomo M, Serafino A, Valli MB, Macioce G, Hassan HJ, Ponzetto A, Clementi M, et al: Molecular characterization and dynamics of hepatitis $C$ virus replication in human fetal hepatocytes infected in vitro. Hepatology 1997, 26:1328-1337.

15. Lazaro CA, Chang M, Tang W, Campbell J, Sullivan DG, Gretch DR, Corey L, Coombs RW, Fausto N: Hepatitis C virus replication in transfected and serum-infected cultured human fetal hepatocytes. Am J Pathol 2007, 170:478-489

16. Song ZQ, Hao F, Min F, Ma QY, Liu GD: Hepatitis C virus infection of human hepatoma cell line 7721 in vitro. World J Gastroenterol 2001, 7:685-689.

17. Kato N, Ikeda M, Mizutani T, Sugiyama K, Noguchi M, Hirohashi S, Shimotohno K: Replication of hepatitis C virus in cultured non-neoplastic human hepatocytes. Jpn J Cancer Res 1996, 87:787-792.

18. Seipp S, Mueller HM, Pfaff E, Stremmel W, Theilmann L, Goeser T: Establishment of persistent hepatitis $C$ virus infection and replication in vitro. J Gen Virol 1997, 78(Pt 10):2467-2476.

19. Mizutani T, Kato N, Saito S, Ikeda M, Sugiyama K, Shimotohno K Characterization of hepatitis $C$ virus replication in cloned cells obtained from a human T-cell leukemia virus type 1-infected cell line, MT-2. J Virol 1996, 70:7219-7223.

20. Shimizu YK, Igarashi $H$, Kiyohara T, Shapiro M, Wong DC, Purcell RH, Yoshikura $\mathrm{H}$ : Infection of a chimpanzee with hepatitis $\mathrm{C}$ virus grown in cell culture. J Gen Virol 1998, 79(Pt 6):1383-1386.

21. Ito T, Mukaigawa J, Zuo J, Hirabayashi Y, Mitamura K, Yasui K: Cultivation of hepatitis $C$ virus in primary hepatocyte culture from patients with chronic hepatitis $C$ results in release of high titre infectious virus. J Gen Virol 1996, 77(Pt 5):1043-1054

22. Blight KJ, Kolykhalov AA, Rice CM: Efficient initiation of HCV RNA replication in cell culture. Science 2000, 290:1972-1974.

23. Lohmann V, Korner F, Koch J, Herian U, Theilmann L, Bartenschlager R: Replication of subgenomic hepatitis C virus RNAs in a hepatoma cell line. Science 1999, 285:110-113.

24. Lohmann V, Hoffmann S, Herian U, Penin F, Bartenschlager R: Viral and cellular determinants of hepatitis $C$ virus RNA replication in cell culture. J Virol 2003, 77:3007-3019.

25. Bartenschlager R: Hepatitis $C$ virus replicons: potential role for drug development. Nat Rev Drug Discov 2002, 1:911-916.

26. Bukh J, Pietschmann T, Lohmann V, Krieger N, Faulk K, Engle RE, Govindarajan S, Shapiro M, St Claire M, Bartenschlager R: Mutations that permit efficient replication of hepatitis $C$ virus RNA in Huh-7 cells prevent productive replication in chimpanzees. Proc Natl Acad Sci USA 2002, 99:14416-14421.

27. Pietschmann T, Lohmann V, Rutter G, Kurpanek K, Bartenschlager R: Characterization of cell lines carrying self-replicating hepatitis $C$ virus RNAs. J Virol 2001, 75:1252-1264.

28. Blight KJ, McKeating JA, Marcotrigiano J, Rice CM: Efficient replication of hepatitis C virus genotype 1a RNAs in cell culture. J Virol 2003, 77:3181-3190.

29. Wakita T, Pietschmann T, Kato T, Date T, Miyamoto M, Zhao Z, Murthy K Habermann A, Krausslich HG, Mizokami M, et al: Production of infectious hepatitis $C$ virus in tissue culture from a cloned viral genome. Nat Med 2005, 11:791-796.

30. Lindenbach BD, Evans MJ, Syder AJ, Wolk B, Tellinghuisen TL, Liu CC, Maruyama T, Hynes RO, Burton DR, McKeating JA, Rice CM: Complete replication of hepatitis C virus in cell culture. Science 2005, 309:623-626.

31. Zhong J, Gastaminza P, Cheng G, Kapadia S, Kato T, Burton DR, Wieland SF, Uprichard SL, Wakita T, Chisari FV: Robust hepatitis C virus infection in vitro. Proc Natl Acad Sci USA 2005, 102:9294-9299.

32. Cai Z, Zhang C, Chang KS, Jiang J, Ahn BC, Wakita T, Liang TJ, Luo G: Robust production of infectious hepatitis $\mathrm{C}$ virus (HCV) from stably HCV cDNA-transfected human hepatoma cells. J Virol 2005, 79:13963-13973.

33. Hsu M, Zhang J, Flint M, Logvinoff C, Cheng-Mayer C, Rice CM, McKeating JA: Hepatitis $C$ virus glycoproteins mediate $\mathrm{pH}$-dependent cell entry of pseudotyped retroviral particles. Proc Natl Acad Sci USA 2003, 100:7271-7276

doi:10.1186/1479-0556-9-7

Cite this article as: Ashfaq et al:: In-vitro model systems to study Hepatitis C Virus. Genetic Vaccines and Therapy 2011 9:7. 